\title{
BIOLOGICAL DIVERSITY OF WEEDS IN A WINTER TRITICALE (Triticum rimpaui Wittm.) CROP DEPENDING ON DIFFERENT DOSES OF HERBICIDES AND FOLIAR FERTILIZATION
}

\author{
Sylwia Andruszczak, Piotr Kraska, Ewa Kwiecińska-Poppe, Edward Pałys
}

\author{
Department of Agricultural Ecology, University of Life Sciences in Lublin, Akademicka 13, 20-950 Lublin, Poland \\ e-mail: sylwia.andruszczak@up.lublin.pl
}

Received: 30.09.2010

\begin{abstract}
A field experiment was conducted in the period 20062008 on incomplete podzolic soil. The present study investigated the effect of different doses of the herbicides Mustang $306 \mathrm{SE}$ and Attribut $70 \mathrm{WG}$ as well as of the foliar fertilizers Insol 3 and FoliCare 18:18:18 on the biodiversity of weeds in a winter triticale crop, 'Todan'. The segetal flora was assessed 6 weeks after the application of the herbicides and before the harvest of the triticale crop. The herbicides were applied together at labelled doses as well as at doses reduced to $75 \%$ and by half. Spraying with the foliar fertilizers was done twice during the growing period. Plots in which no herbicides or foliar fertilizers were used were the control treatment.

Matricaria maritima and Viola arvensis from the dicotyledonous class were predominant in the winter triticale crop, whereas Apera spica-venti was the dominant species among the monocotyledons. The weed control efficacy of the reduced herbicide doses was weaker compared to the labelled rates by, respectively, from $6 \%$ to $9 \%$ at the first time of weed infestation assessment and from $4 \%$ to $8 \%$ at the second assessment time. Simultaneously, air-dry weight of weeds in the herbicide-treated plots did not differ significantly. This indicates that it is possible to reduce herbicide doses in a winter triticale crop without a risk of increased weed infestation.
\end{abstract}

Key words: winter triticale, weed biodiversity, herbicide doses, foliar fertilization

\section{INTRODUCTION}

The currently observed biodiversity of segetal communities has been shaped under the influence of long-term human activity, in particular weed management methods (R o la et al. 1999). The weed control concept has been modified in recent years, since it has been concluded that the complete removal of weeds is not always necessary. Taking into account yields obtained, it is possible to reduce weed infestation to a level that does not pose any threat to crop plants (Dobrzański and Adamczewski, 2009). This changed perception of weed management entails the application of reduced herbicide doses (B la ck $\mathrm{s} \mathrm{h}$ a w et al. 2006). Numerous studies show that reducing herbicide doses clearly decreases the occurrence of weeds and effectively weakens their form. At the same time, this does not cause any significant decrease in yields of crop plants and is beneficial not only from the point of view of environmental protection, but also for economic reasons (Davies and Whiting, 1989; Romek and Dzienia, 2000; Zhang et al. 2000; Domaradzki and Sadowski, 2002; Kraska et al. 2009).

The level and type of fertilization applied can be a factor that modifies the structure of agrophytocenoses. Studies of many authors show that an adequate supply of all necessary macro- and micronutrients to plants, through the beneficial effect on the crop content, reduces the weed infestation level and differentiates the species composition of weeds ( $\mathrm{S}$ tępień, 2004; B l e c harcz y k et al. 2009).

The aim of the present study was to determine the biodiversity of weeds in a winter triticale crop grown under the conditions of application of reduced herbicide doses and foliar fertilization.

\section{MATERIALS AND METHODS}

The present field experiment was conducted in the period 2006-2008 in the Bezek Experimental Farm, belonging to the University of Life Sciences in Lublin. The experimental field was located on incomplete podzolic soil lying on marl substrate with the granulometric composition of loamy sand. This soil is 
classified as soil class IVb and good rye complex. It was characterized by slightly acidic $\mathrm{pH}(\mathrm{pH}$ in $1 \mathrm{~mol}$ $\mathrm{KCl}$ 6.0), high phosphorus content $\left(74.6 \mathrm{mg} \times \mathrm{kg}^{-1}\right)$, average potassium content $\left(99.6 \mathrm{mg} \times \mathrm{kg}^{-1}\right)$, and low magnesium content $\left(22.0 \mathrm{mg} \times \mathrm{kg}^{-1}\right)$. The humus content was $1.2 \%$.

The two-factor experiment, set up in a randomized block design with three replicates, investigated and compared the effects of three herbicide doses and two foliar fertilizers in a winter triticale Triticum rimpaui Wittm. crop, cv. Todan. Spraying with the herbicides

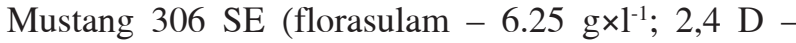
$300{\mathrm{~g} \times{ }^{-1}}^{-1}$ ) and Attribut $70 \mathrm{WG}$ (propoxycarbazone-sodium $-70 \%$ ) was done in the spring at the full tillering stage of winter triticale (phase 23/25 in the $\mathrm{BBCH}$ scale that is used to identify phytophenological phases of crop plants). The herbicides were applied together at full labelled doses (respectively, $400 \mathrm{ml} \times \mathrm{ha}^{-1}$ and

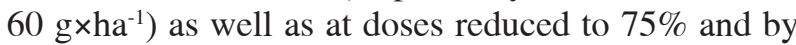
half. Foliar fertilization was done twice during the growing season at the tillering and stem elongation stages (BBCH $23 / 25$ and 33/35), using the foliar fertilizers Insol 3 at a rate of $11 \times \mathrm{ha}^{-1}$ and FoliCare 18:18:18 at $20 \mathrm{~kg} \times \mathrm{ha}^{-1}$. The chemical composition of these fertilizers is presented in Table 1. Plots in which no herbicides or foliar fertilizers were used were the control treatment. Additionally, the following fungicides were used: Alert $375 \mathrm{SC}$ at a rate of $11 \times \mathrm{ha}^{-1}(\mathrm{BBCH}$ 26-29) and Tango $500 \mathrm{SC}$ at $0.81 \times \mathrm{ha}^{-1}$ (BBCH 51-56), as well as the growth retardant Tergal $\mathrm{C} 460 \mathrm{SL}$ at a rate of $2.51 \times \mathrm{ha}^{-1}(32-39 \mathrm{BBCH})$. Tillage was performed following generally accepted agricultural practice recommendations. Seeds, dressed with the seed dresser Panoctine $300 \mathrm{LS}\left(300 \mathrm{~g} \times \mathrm{l}^{-1}\right.$ - guazatine in the form of acetate), were sown at an amount of 500 grains per $1 \mathrm{~m}^{2}$. Mineral fertilizer rates were as follows: $\mathrm{N}$ $120 \mathrm{~kg} \times \mathrm{ha}^{-1} ; \mathrm{P}-43.6 \mathrm{~kg} \times \mathrm{ha}^{-1} ; \mathrm{K}-99.6 \mathrm{~kg} \times \mathrm{ha}^{-1}$.

Weed infestation of the crop was determined twice using the quantitative gravimetric method; the first time 6 weeks after the herbicide treatment, while the second time before the harvest of winter triticale. Number of weeds, weed species composition and airdry weight of the above-ground parts of weeds were determined based on the sampling sites marked out by a $1 \mathrm{~m} \times 0.25 \mathrm{~m}$ frame, in four randomly selected places in each plot. The obtained results were statistically processed using analysis of variance and least significant differences were calculated using Tukey's confidence half-intervals with a $5 \%$ risk of error.

\section{RESULTS AND DISCUSSION}

A winter triticale crop meets the essential conditions for good competitiveness against weeds thanks to relatively wide leaf blades of this plant, high crop density, and good tillering ability. At the same time, triticale, as an interspecific hybrid, exhibits higher sensitivity to weed infestation than rye, which results primarily from its slow growth rate at the initial stage of plant development and from the sensitivity of cultivated cultivars to climatic conditions ( $\mathrm{Hru} \mathrm{s} \mathrm{z} \mathrm{ka \text {, }}$ 2005). Irrespective of the experimental factors, during the first assessment of weed infestation a total of 29 weed species were identified, among which Equisetum arvense and 4 species from the group of monocotyledones weeds were found, while the remaining species belonged to the dicotyledonous class (Tables 2 and 4). The character of this agrophytocenosis was formed by two dominant species, i.e. Matricaria maritima subsp. inodora and Viola arvensis, which accounted respectively for $30.2 \%$ and $26.0 \%$ of the total number of weeds. Veronica arvensis, Galium aparine, Stellaria media and Geranium pusillum from the dicotyledons (comprising from $4.3 \%$ to $9.8 \%$ ) as well as Apera spica-venti and Poa апnиa from the monocotyledones class (accounting respectively for $8.6 \%$ and $2.4 \%$ ) were found in much smaller numbers. The remaining taxa occurred sporadically, with each of them constituting $2 \%$ or less in the community.

Before the harvest of the winter triticale crop, 33 weed species were identified, out of which 6 belonged to the monocotyledones class (Tables 3 and 5). It should be stressed that at the second assessment time 12 species appeared that had not been found during the previous assessment. The following belonged to them, among others: Cerastium arvense, Plantago major, Anagallis arvensis, Setaria viridis, and Echinochloa crus-galli. One should suppose that this was attributable to diaspores found in the soil seed bank, whose emergence occurred during the later part of the growing season. Apera spica-venti, whose percentage in the total number of weeds was $44.6 \%$, was an absolute dominant at this assessment time. Among the dicotyledons species, Viola arvensis and Matricaria maritima were represented in greatest numbers (respectively, 15.9\% and 10.3\%). Analysing the species composition of the weeds colonizing the winter triticale crops, it can be said that, in the light of the literature data, it was typical for this cereal crop (K $1 \mathrm{i}$ k ocka, 2000; Rychcik and Sadowski, 2007; Kraska, 2008).

The applied herbicides Mustang 306 SE and Attribut 70 WG differentiated the number and species composition of weeds in the winter triticale crops. At the first time of weed infestation assessment (Table 2 ), the weed control efficacy of the above-mentioned weed killers averaged from $38 \%$ to $52 \%$. K r a s k a (2008), when applying Atlantis 04 WG and Factor 365 EC in a winter triticale crop, achieved higher effectiveness of herbicide action. Among the herbicide 
treatments, the plots treated with the herbicides applied at half doses were characterized by the greatest species diversity. The study of $\mathrm{Kraska}$ (2008) shows a similar correlation in a winter triticale crop. The herbicide treatments clearly reduced the numbers in the case of most of the weed species. Regardless of the herbicide dose used, the following weed species, inter alia, were found in smaller numbers compared to the control treatment: Matricaria maritima (from 51\% to $75 \%$ ), Galium aparine (from $67 \%$ to $74 \%$ ), Stellaria media (from $62 \%$ to $92 \%$ ), and Anthemis arvensis (from $77 \%$ to $96 \%$ ). Moreover, the application of the herbicides at the full recommended dose and at a dose reduced to $75 \%$ eliminated 6 weed species from the crop in each case. At the same time, taxa such as $\mathrm{Co}$ nyza canadensis, Lamium amplexicaule, Setaria pumila, and Equisetum arvense appeared sporadically. D o maradzki (2006) draws attention to the varied species-specific sensitivity of weeds to the active substances of herbicides. According to this author, some taxa exhibit a strong response to weed control agents applied at rates reduced from $50 \%$ to $75 \%$, whereas some other ones can be eliminated only when herbicides are applied at recommended amounts.

During the estimation of weed infestation of the winter triticale crop before harvest (Table 3), on average 1 to 2 weed species more were found in the herbicide treatments than in the control plots. The herbicides Mustang 306 SE and Attribut 70 WG, depending on the applied dose, clearly reduced the number of $\mathrm{Co}$ nyza canadensis (from 65 to $75 \%$ ), Chenopodium album (from 59 to 77\%), and Matricaria maritima (from 24 to $49 \%$ ), but these herbicides were found to show the highest weed control effectiveness against Apera spica-venti (70-76\%). R o me $\mathrm{k}$ and $\mathrm{Dz}$ i enia (2000) report that reduction of the doses of the herbicides Protugan 500 SC, Lentipur 80 WP, and Chisel 75 DF by half decreased the weed control efficacy against Apera spica-venti by $15 \%$ to $31 \%$, on average. In the experiment under discussion, the effect of the below-labelled rates of the weed control agents Mustang 306 SE and Attribut $70 \mathrm{WG}$ against this species was weaker by only $2 \%$ to $6 \%$ than that of the full labelled rates.

It is characteristic that the proportion of Viola arvensis, both during the first and second assessment time, in the herbicide treatments was higher than that under the control conditions, which was probably attributable to low sensitivity of this species to the active substances of the herbicides applied. According to Romek and D zie nia (2000), increased weed infestation of crop fields caused by Viola arvensis and other resistant species results from the common application of active substances that are not very effective in killing some dicotyledons weed species. In effect, Viola arvensis can reach the height of a mature cereal crop and cause substantial crop losses ( M i k la s z e w s k a et al. 1996).

Foliar feeding of the plants changed weed biodiversity in the winter triticale crop. Irrespective of the herbicide dose, during the first assessment of weed infestation the weed communities averaged from 50.5 to 58.6 pieces per $1 \mathrm{~m}^{2}$, with dicotyledons species accounting for $85 \%$ to $90 \%$ (Table 4 ). The effect of the application of the fertilizer Insol 3, as a result of better nutrition of the triticale plants and their increased competitive ability, was the elimination of 6 weed species from the crop, with the simultaneous appearance of single individuals of Cirsium arvense. The numbers of most taxa in this treatment generally decreased under the influence of the fertilizer applied, except for Capsella bursa-pastoris, Vicia hirsuta, Polygonum aviculare, Lamium amplexicaule, and Apera spica-venti. In the treatments sprayed with the fertilizer FoliCare 18:18:18, six weed species, including Matricaria maritima and Veronica arvensis, exhibited greater numbers relative to the treatment without foliar fertilizers. Three taxa (Galinsoga parviflora, Polygonum aviculare, and Sonchus arvensis) were eliminated from the crop, while Cirsium arvense, Conyza canadensis, Setaria pumila, and Equisetum arvense appeared additionally.

Before the harvest of the winter triticale crop (Table 5), a total of 27 taxa were found in the control treatments without foliar fertilizers, including 21 from the dicotyledons class. Under the influence of the foliar fertilizers Insol 3 and FoliCare 18:18:18, the number of weed species decreased to 24 and 25, respectively.

An important measure in weed infestation assessment is air-dry weight of the above-ground mass produced by weeds. In the present experiment, the value of this trait was significantly affected only by the herbicide treatments applied (Table 6). During the first assessment of weed infestation, the weed control efficacy of the herbicides Mustang 306 SE and Attribut 70 WG averaged from $73 \%$ to $81 \%$, whereas at the second assessment time it was from $61 \%$ to $69 \%$. It is worth noting that a significant decrease in air-dry weight of weeds was obtained, relative to the control treatment, after the application of the herbicides both at labelled and below-labelled rates. At the same time, the differences between the herbicide treatments were within the margin of statistical error. Starczewski and $\dot{Z}$ ą d e łe k (2000) showed that reduction of the rates of the herbicides Arelon 75 WP and Puma Super 069 EC by half decreased the effectiveness of their action by $8 \%$, while in the study of R o m e k and D z i e n i a (2000) the efficacy of the weed control agents Protugan $500 \mathrm{SC}$, Lentipur $80 \mathrm{WP}$, and Chisel $75 \mathrm{DF}$ was reduced by $12 \%$ up to $17 \%$. 
Table 1.

Chemical composition of foliar fertilizers (\%)

\begin{tabular}{cccccccccccc}
\hline Foliar fertilizer & $\mathrm{N}$ & $\mathrm{P}$ & $\mathrm{K}$ & $\mathrm{Mg}$ & $\mathrm{S}$ & $\mathrm{B}$ & $\mathrm{Cu}$ & $\mathrm{Fe}$ & $\mathrm{Mn}$ & $\mathrm{Mo}$ & $\mathrm{Zn}$ \\
\hline $\begin{array}{c}\text { Insol 3 } \\
\text { FoliCare }\end{array}$ & 11.5 & - & - & 2.84 & - & 0.28 & 0.56 & 1.20 & 1.68 & 0.01 & 1.12 \\
18:18:18 & 18.0 & 18.1 & 18.0 & 1.5 & 7.2 & 0.02 & 0.10 & 0.20 & 0.10 & 0.01 & 0.02 \\
\hline
\end{tabular}

Table 2.

Species composition and number of weeds per $1 \mathrm{~m}^{2}$ in the winter triticale crop at the first time of weed infestation assessment depending on the herbicide dose, mean for 2006-2008

\begin{tabular}{|c|c|c|c|c|c|}
\hline \multirow{2}{*}{ No. } & \multirow{2}{*}{ Weed species } & \multicolumn{4}{|c|}{ Herbicide dose } \\
\hline & & Control treatment & $100 \%$ & $75 \%$ & $50 \%$ \\
\hline & Dicotyledons & & & & \\
\hline 1 & Matricaria maritima subsp. inodora(L.) & 31.9 & 7.9 & 12.2 & 15.6 \\
\hline 2 & Viola arvensis Murray & 13.7 & 15.4 & 14.5 & 14.3 \\
\hline 3 & Galium aparine $\mathrm{L}$. & 7.0 & 1.8 & 2.0 & 2.3 \\
\hline 4 & Stellaria media (L.) Vill. & 6.5 & 0.5 & 1.2 & 2.5 \\
\hline 5 & Veronica arvensis L. & 4.4 & 4.9 & 4.8 & 7.7 \\
\hline 6 & Geranium pusillum L. & 2.6 & 1.6 & 2.8 & 2.7 \\
\hline 7 & Anthemis arvensis L. & 2.6 & 0.6 & 0.2 & 0.1 \\
\hline 8 & Capsella bursa-pastoris L. & 2.0 & 0.1 & 0.1 & 0.3 \\
\hline 9 & Chenopodium album $\mathrm{L}$. & 1.6 & 0.1 & 0.3 & 0.2 \\
\hline 10 & Myosotis arvensis L. & 1.2 & 0.2 & 0.4 & 0.7 \\
\hline 11 & Vicia hirsuta (L.) Gray & 0.4 & 0.0 & 0.1 & 0.0 \\
\hline 12 & Melandrium album (Mill.) & 0.4 & - & 0.0 & 0.0 \\
\hline 13 & Centaurea cyanus L. & 0.3 & 0.1 & - & - \\
\hline 14 & Convolvulus arvensis L. & 0.2 & 0.2 & 0.2 & 0.0 \\
\hline 15 & Stachys palustris $\mathrm{L}$. & 0.2 & 0.2 & - & 0.0 \\
\hline 16 & Fallopia convolvulus L. & 0.2 & 0.1 & - & 0.0 \\
\hline 17 & Papaver rhoeas L. & 0.2 & - & - & 0.0 \\
\hline 18 & Cirsium arvense $\mathrm{L}$. & 0.1 & - & 0.1 & 0.0 \\
\hline 19 & Galinsoga parviflora Cav. & 0.1 & - & - & - \\
\hline 20 & Sonchus arvensis L. & 0.0 & - & 0.0 & 0.0 \\
\hline 21 & Veronica persica Poir. & 0.0 & - & - & 0.0 \\
\hline 22 & Conyza canadensis $\mathrm{L}$. & - & 0.1 & 0.2 & - \\
\hline 23 & Lamium amplexicaule $\mathrm{L}$. & - & 0.0 & 0.1 & 0.1 \\
\hline \multirow[t]{4}{*}{24} & Polygonum aviculare $\mathrm{L}$. & - & - & - & 0.3 \\
\hline & Total dicotyledons weeds & 75.6 & 33.8 & 39.2 & 46.8 \\
\hline & Number of dicotyledons species & 21 & 17 & 17 & 21 \\
\hline & Monocotyledones & & & & \\
\hline 25 & Apera spica-venti $\mathrm{L}$. & 5.8 & 3.7 & 5.8 & 3.9 \\
\hline 26 & Elymus repens $\mathrm{L}$. & 1.6 & 0.6 & 0.4 & 0.7 \\
\hline 27 & Pоа аппиа $\mathrm{L}$. & 0.9 & 1.5 & 2.1 & 0.8 \\
\hline 28 & Setaria pumila (Poir.) Roem. \& Schult & - & 0.3 & - & - \\
\hline \multirow[t]{4}{*}{29} & Equisetum arvense $\mathrm{L}$. & - & - & 0.0 & - \\
\hline & Total monocotyledones weeds & 8.3 & 6.1 & 8.3 & 5.4 \\
\hline & Number of monocotyledones species & 3 & 4 & 4 & 3 \\
\hline & Total number of weeds & 83.9 & 39.9 & 47.5 & 52.2 \\
\hline
\end{tabular}

0.0 - species numbering less than 0.1 pcs. per $1 \mathrm{~m}^{2}$ 
Table 3.

Species composition and number of weeds per $1 \mathrm{~m}^{2}$ in the winter triticale crop

at the second time of weed infestation assessment depending on the herbicide dose, mean for 2006-2008

\begin{tabular}{|c|c|c|c|c|c|}
\hline \multirow{2}{*}{ No. } & \multirow{2}{*}{ Weed species } & \multicolumn{4}{|c|}{ Herbicide dose } \\
\hline & & Control treatment & $100 \%$ & $75 \%$ & $50 \%$ \\
\hline & Dicotyledons & & & & \\
\hline 1 & Matricaria maritima subsp. inodora(L.) & 3.7 & 1.9 & 2.8 & 2.7 \\
\hline 2 & Viola arvensis Murray & 2.2 & 5.2 & 5.6 & 4.3 \\
\hline 3 & Chenopodium album $\mathrm{L}$. & 2.2 & 0.9 & 0.5 & 0.7 \\
\hline 4 & Conyza canadensis $\mathrm{L}$. & 2.0 & 0.5 & 0.5 & 0.7 \\
\hline 5 & Geranium pusillum L. & 0.6 & 1.1 & 0.5 & 1.0 \\
\hline 6 & Fallopia convolvulus L. & 0.6 & 0.6 & 0.4 & 0.4 \\
\hline 7 & Myosotis arvensis L. & 0.4 & 1.0 & 0.2 & 0.3 \\
\hline 8 & Cerastium arvense L. & 0.4 & 0.2 & 0.5 & 0.2 \\
\hline 9 & Centaurea cyanus L. & 0.4 & 0.2 & 0.1 & 0.1 \\
\hline 10 & Stellaria media (L.) Vill. & 0.3 & 0.3 & - & 0.6 \\
\hline 11 & Polygonum aviculare L. & 0.2 & 0.3 & 0.3 & 0.0 \\
\hline 12 & Plantago major L. & 0.2 & 0.2 & - & - \\
\hline 13 & Capsella bursa-pastoris L. & 0.2 & 0.1 & 0.2 & - \\
\hline 14 & Vicia hirsuta (L.) Gray & 0.2 & - & 0.2 & 0.1 \\
\hline 15 & Anagallis arvensis L. & 0.1 & 0.2 & - & - \\
\hline 16 & Veronica arvensis L. & 0.1 & 0.2 & - & - \\
\hline 17 & Papaver rhoeas $\mathrm{L}$. & 0.1 & - & - & 0.0 \\
\hline 18 & Galium aparine $\mathrm{L}$. & - & 0.3 & 0.6 & 0.4 \\
\hline 19 & Stachys palustris L. & - & 0.2 & 0.0 & - \\
\hline 20 & Hypericum perforatum $\mathrm{L}$. & - & 0.1 & - & 0.2 \\
\hline 21 & Gypsophila muralis L. & - & 0.1 & - & 0.0 \\
\hline 22 & Amaranthus retroflexus L. & - & - & 0.2 & - \\
\hline 23 & Cirsium arvense $\mathrm{L}$. & - & - & 0.1 & - \\
\hline 24 & Medicago lupulina $\mathrm{L}$. & - & - & 0.1 & - \\
\hline 25 & Gnaphalium uliginosum L. & - & - & 0.0 & - \\
\hline 26 & Sonchus arvensis $\mathrm{L}$. & - & - & - & 0.0 \\
\hline \multirow[t]{4}{*}{27} & Urtica dioica $\mathrm{L}$. & - & - & - & 0.0 \\
\hline & Total dicotyledons weeds & 13.9 & 13.6 & 12.8 & 11.7 \\
\hline & Number of dicotyledons species & 17 & 19 & 18 & 18 \\
\hline & Monocotyledons & & & & \\
\hline 28 & Apera spica-venti $\mathrm{L}$. & 27.0 & 6.4 & 6.9 & 8.1 \\
\hline 29 & Elymus repens L. & 1.5 & 1.0 & 1.3 & 1.4 \\
\hline 30 & Setaria viridis (L.) P. Beauv. & 0.4 & 0.1 & 0.1 & 0.6 \\
\hline 31 & Poa annua $\mathrm{L}$. & 0.0 & 0.1 & 0.3 & 0.2 \\
\hline 32 & Bromus secalinus L. & 0.0 & - & - & - \\
\hline \multirow[t]{4}{*}{33} & Echinochloa crus-galli (L.) P. Beauv. & - & 0.4 & 0.4 & 0.2 \\
\hline & Total monocotyledones weeds & 28.9 & 8.0 & 9.0 & 10.5 \\
\hline & Number of monocotyledones species & 5 & 5 & 5 & 5 \\
\hline & Total number of weeds & 42.8 & 21.6 & 21.8 & 22.2 \\
\hline
\end{tabular}

0.0 - species numbering less than 0.1 pcs. per $1 \mathrm{~m}^{2}$ 
Table 4.

Species composition and number of weeds per $1 \mathrm{~m}^{2}$ in the winter triticale crop at the first time of weed infestation assessment depending on foliar fertilization, mean for 2006-2008

\begin{tabular}{|c|c|c|c|c|}
\hline No. & Weed species & $\begin{array}{l}\text { Control } \\
\text { treatment }\end{array}$ & Insol 3 & $\begin{array}{c}\text { Foli Care } \\
18: 18: 18\end{array}$ \\
\hline & Dicotyledons & & & \\
\hline 1 & Matricaria maritima subsp. inodora(L.) & 16.4 & 16.2 & 18.0 \\
\hline 2 & Viola arvensis Murray & 15.0 & 13.6 & 14.9 \\
\hline 3 & Veronica arvensis L. & 6.0 & 4.1 & 6.3 \\
\hline 4 & Galium aparine $\mathrm{L}$. & 3.7 & 2.5 & 3.6 \\
\hline 5 & Stellaria media (L.) Vill. & 3.4 & 1.5 & 3.1 \\
\hline 6 & Geranium pusillum L. & 2.6 & 2.4 & 2.2 \\
\hline 7 & Anthemis arvensis $\mathrm{L}$. & 0.9 & 0.3 & 1.4 \\
\hline 8 & Chenopodium album $\mathrm{L}$. & 0.8 & 0.3 & 0.5 \\
\hline 9 & Myosotis arvensis L. & 0.7 & 0.5 & 0.6 \\
\hline 10 & Capsella bursa-pastoris L. & 0.4 & 0.6 & 0.9 \\
\hline 11 & Convolvulus arvensis $\mathrm{L}$. & 0.3 & 0.1 & 0.1 \\
\hline 12 & Melandrium album (Mill.) & 0.2 & - & 0.1 \\
\hline 13 & Vicia hirsuta (L.) Gray & 0.1 & 0.2 & 0.1 \\
\hline 14 & Fallopia convolvulus L. & 0.1 & 0.1 & 0.1 \\
\hline 15 & Centaurea cyanus L. & 0.1 & - & 0.2 \\
\hline 16 & Stachys palustris L. & 0.1 & - & 0.2 \\
\hline 17 & Papaver rhoeas $\mathrm{L}$. & 0.1 & - & 0.1 \\
\hline 18 & Galinsoga parviflora Cav. & 0.1 & - & - \\
\hline 19 & Polygonum aviculare L. & 0.0 & 0.2 & - \\
\hline 20 & Lamium amplexicaule L. & 0.0 & 0.1 & 0.0 \\
\hline 21 & Sonchus arvensis L. & 0.0 & 0.0 & - \\
\hline 22 & Veronica persica Poir. & 0.0 & - & 0.0 \\
\hline 23 & Cirsium arvense $\mathrm{L}$. & - & 0.1 & 0.1 \\
\hline \multirow[t]{4}{*}{24} & Conyza canadensis $\mathrm{L}$. & - & - & 0.2 \\
\hline & Total dicotyledons weeds & 51.0 & 42.8 & 52.7 \\
\hline & Number of dicotyledons species & 22 & 17 & 21 \\
\hline & Monocotyledones & & & \\
\hline 25 & Apera spica-venti $\mathrm{L}$. & 5.0 & 6.0 & 3.4 \\
\hline 26 & Poa annua $\mathrm{L}$. & 1.6 & 1.1 & 1.3 \\
\hline 27 & Elymus repens L. & 0.8 & 0.6 & 1.0 \\
\hline 28 & Setaria pumila (Poir.) Roem. \& Schult & - & - & 0.2 \\
\hline \multirow[t]{4}{*}{29} & Equisetum arvense $\mathrm{L}$. & - & - & 0.0 \\
\hline & Total monocotyledones weeds & 7.4 & 7.7 & 5.9 \\
\hline & Number of monocotyledones species & 3 & 3 & 5 \\
\hline & Total number of weeds & 58.4 & 50.5 & 58.6 \\
\hline
\end{tabular}

0.0 - species numbering less than 0.1 pes. per $1 \mathrm{~m}^{2}$ 
Table 5.

Species composition and number of weeds per $1 \mathrm{~m}^{2}$ in the winter triticale crop at the second time of weed infestation assessment depending on foliar fertilization, mean for 2006-2008

\begin{tabular}{|c|c|c|c|c|}
\hline No. & Weed species & $\begin{array}{l}\text { Control } \\
\text { treatment }\end{array}$ & Insol 3 & $\begin{array}{c}\text { Foli Care } \\
\text { 18:18:18 }\end{array}$ \\
\hline & Dicotyledons & & & \\
\hline 1 & Viola arvensis Murray & 4.8 & 5.0 & 3.2 \\
\hline 2 & Matricaria maritima subsp. inodora(L.) & 2.9 & 2.9 & 2.6 \\
\hline 3 & Chenopodium album $\mathrm{L}$. & 1.2 & 0.9 & 1.1 \\
\hline 4 & Geranium pusillum $\mathrm{L}$. & 1.2 & 0.6 & 0.5 \\
\hline 5 & Conyza canadensis $\mathrm{L}$. & 1.1 & 1.0 & 0.7 \\
\hline 6 & Myosotis arvensis $\mathrm{L}$. & 0.7 & 0.3 & 0.4 \\
\hline 7 & Fallopia convolvulus $\mathrm{L}$. & 0.6 & 0.4 & 0.4 \\
\hline 8 & Cerastium arvense L. & 0.2 & 0.4 & 0.4 \\
\hline 9 & Stellaria media (L.) Vill. & 0.2 & 0.4 & 0.3 \\
\hline 10 & Centaurea cyanus $\mathrm{L}$. & 0.2 & 0.3 & 0.1 \\
\hline 11 & Polygonum aviculare $\mathrm{L}$. & 0.2 & 0.1 & 0.3 \\
\hline 12 & Vicia hirsuta (L.) Gray & 0.2 & 0.1 & 0.1 \\
\hline 13 & Plantago major $\mathrm{L}$. & 0.2 & 0.1 & - \\
\hline 14 & Stachys palustris $\mathrm{L}$. & 0.2 & - & - \\
\hline 15 & Galium aparine $\mathrm{L}$. & 0.1 & 0.4 & 0.5 \\
\hline 16 & Capsella bursa-pastoris L. & 0.1 & 0.1 & 0.1 \\
\hline 17 & Anagallis arvensis L. & 0.1 & - & 0.1 \\
\hline 18 & Veronica arvensis $\mathrm{L}$. & 0.1 & - & 0.1 \\
\hline 19 & Cirsium arvense $\mathrm{L}$. & 0.1 & - & - \\
\hline 20 & Gypsophila muralis L. & 0.0 & 0.1 & - \\
\hline 21 & Papaver rhoeas $\mathrm{L}$. & 0.0 & - & 0.0 \\
\hline 22 & Hypericum perforatum $\mathrm{L}$. & - & 0.1 & 0.1 \\
\hline 23 & Gnaphalium uliginosum $\mathrm{L}$. & - & 0.0 & - \\
\hline 24 & Urtica dioica $\mathrm{L}$. & - & 0.0 & - \\
\hline 25 & Amaranthus retroflexus $\mathrm{L}$. & - & - & 0.2 \\
\hline 26 & Medicago lupulina $\mathrm{L}$. & - & - & 0.1 \\
\hline \multirow[t]{4}{*}{27} & Sonchus arvensis L. & - & - & 0.0 \\
\hline & Total dicotyledons weeds & 14.4 & 13.2 & 11.4 \\
\hline & Number of dicotyledons species & 21 & 19 & 21 \\
\hline & Monocotyledones & & & \\
\hline 28 & Apera spica-venti $\mathrm{L}$. & 11.1 & 10.8 & 14.4 \\
\hline 29 & Echinochloa crus-galli (L.) P. Beauv. & 0.3 & 0.2 & 0.3 \\
\hline 30 & Setaria viridis (L.) P. Beauv. & 0.3 & 0.2 & 0.3 \\
\hline 31 & Elymus repens $\mathrm{L}$. & 1.2 & 1.5 & 1.3 \\
\hline 32 & Роа аппиа $\mathrm{L}$. & 0.0 & 0.4 & - \\
\hline \multirow[t]{4}{*}{33} & Bromus secalinus $\mathrm{L}$. & 0.0 & - & - \\
\hline & Total monocotyledones weeds & 12.9 & 13.1 & 16.3 \\
\hline & Number of monocotyledones species & 6 & 5 & 4 \\
\hline & Total number of weeds & 27.3 & 26.3 & 27.7 \\
\hline
\end{tabular}

0.0 - species numbering less than $0.1 \mathrm{pcs}$. per $1 \mathrm{~m}^{2}$ 
Table 6.

Air-dry weight of weeds per $1 \mathrm{~m}^{2}$ in the winter triticale crop (mean for 2006-2008)

\begin{tabular}{|c|c|c|c|c|c|}
\hline \multirow{2}{*}{ Foliar fertilizer } & \multicolumn{4}{|c|}{ Herbicide dose } & \multirow{2}{*}{ Mean } \\
\hline & Control treatment & $100 \%$ & $75 \%$ & $50 \%$ & \\
\hline & \multicolumn{5}{|c|}{ First time of weed infestation assessment } \\
\hline Control treatment & 103.1 & 12.6 & 24.7 & 26.0 & 41.6 \\
\hline Insol 3 & 85.8 & 19.0 & 21.5 & 25.6 & 38.0 \\
\hline Foli Care 18:18:18 & 124.4 & 27.1 & 31.0 & 34.2 & 54.2 \\
\hline Mean & 104.4 & 19.6 & 25.7 & 28.6 & - \\
\hline \multirow[t]{2}{*}{$\mathrm{LSD}_{0.05}$} & \multicolumn{5}{|c|}{ Between herbicide doses 28.02} \\
\hline & \multicolumn{5}{|c|}{ Second time of weed infestation assessment } \\
\hline Control treatment & 64.7 & 29.8 & 28.4 & 22.7 & 36.4 \\
\hline Insol 3 & 53.7 & 14.8 & 23.0 & 33.6 & 31.3 \\
\hline Foli Care 18:18:18 & 80.5 & 16.9 & 17.7 & 20.8 & 34.0 \\
\hline Mean & 66.3 & 20.5 & 23.0 & 25.7 & - \\
\hline $\mathrm{LSD}_{0.05}$ & \multicolumn{5}{|c|}{ Between herbicide doses 24.79} \\
\hline
\end{tabular}

\section{CONCLUSIONS}

Matricaria maritima, Viola arvensis, and Apera spica-venti were the species that occurred in greatest numbers in the winter triticale crop at both assessment times.

The species composition and numbers of weeds depended primarily on the applied doses of the herbicides Mustang 306 SE and Attribut 70 WG. Foliar fertilization did not have a significant effect on both weed species diversity and weed density.

At the first assessment time, the applied herbicides reduced to the greatest extent the occurrence of Matricaria maritima, Galium aparine, Stellaria media, and Anthemis arvensis. Before the harvest of the winter triticale crop, a substantial decrease in the number of individuals of Apera spica-venti, Chenopodium album, Conyza canadensis and Matricaria maritime was found.

Air-dry weight of weeds in the herbicide treatments did not differ significantly. This indicates that it is possible to reduce herbicide doses in a winter triticale crop without a risk of increased weed infestation

\section{REFERENCES}

Blackshaw R.E., O'Donovan J.T., Harker K.N., Clayton G.W., Stougaard R.N. 2006. Reduced herbicide doses in field crops: A review. Weed Biol. Management 6: 10-17.

Blecharczyk A., Małecka I., Sawińska Z., Zawada D. 2009. Effect of fertilization on weed biodiversity in long-term continuous winter rye. Post. Ochr. Roślin / Prog. Plant Protection, 49 (1): 322-325.

Davies D.H.K., Whiting A.J. 1989. Yield responses to herbicide use and weed levels in winter wheat and spring barley in scotish trials and consequences for economic models. The BCPC Conference - Weeds, 3: 955-960

Dobrzański A., Adamczewski K. 2009. The influence of weed control on agrophytocenosis biodiversity. Post. Ochr. Roślin / Prog. Plant Protection 49(3): 982-995.

Domaradzki K. 2006. Effectiveness of the weed control in cereals in the aspect of reducing herbicide doses and selected agroecological factors. IUNG Puławy, Monografie i rozprawy naukowe, pp. 111.

Domaradzki K., Sadowski J. 2002. The possibility of reduction of load for natural environment by applying the herbicide in limited doses. Pam. Pul. 130/I: 99-114.

Hruszka M. 2005. Pro-ecological methods of weeds control and their role in the protection of winter triticale crop. Post. Ochr. Roślin / Prog. Plant Protection 45(2): 712-715.

Klikocka H. 2000. Effect of differentiated soil cultivation and fertilization on weeding of spring triticale. Ann. UMCS, Sect. E, 55, Suppl.: 85-96.

Kraska P. 2008. The influence of different herbicide doses on weed infestation of winter triticale cultivated in monoculture. Acta Agrobot. 61(2): 229-238.

Kraska P., Okoń S., Pałys E. 2009. Weed infestation of a winter wheat canopy under the conditions of application of different herbicide doses and foliar fertilization. Acta Agrobot. 62(2): 193-206.

Miklaszewska K., Adamczewski K., Ratajczyk G. 1996. Występowanie Viola arvensis w jęczmieniu ozimym - wpływ na plon i zwalczanie. / The occurrence of 
Viola arvensis in winter barley - the effect on yield and its control. Post. Ochr. Roślin / Prog. Plant Protection 36(2): 273-276. (in Polish)

Romek B., Dzienia S. 2000. Efficacy of applying full and reduced doses of herbicides in winter triticale. Ann. UMCS, Sect. E, 55, Suppl.: 181-186.

Rychcik B., Sadowski T. 2007. Comparison of herbicidal and mechanical methods of weeds regulation in winter triticale. Post. Ochr. Roślin / Prog. Plant Protection 47(3): 242-245.

Rola H., Rola J., Zaliwski A. 1999. Monitoring stanu i stopnia zachwaszczenia upraw rolniczych w Polsce. / Monitoring of weed infestation status and levels in agricultural crops in Poland. Post. Ochr. Roślin / Prog. Plant Protection 39(1): 289-297. (in Polish)

Starczewski J., Żądełek J. 2000. Effect of quantity of seeding and reduction of doses of herbicides on weed infestation and yielding of triticale. Ann. UMCS, Sect. E, 55, Suppl.: 187-195.

S tę pi én A. 2004. Effect of different fertilization methods on weed infestation and yielding of spring wheat. Acta Sci. Pol. Agricult. 3(1): 45-54.

Wesołowski M., Woźniak A. 2000. Weed infestation of winter triticale in relation to the forecrop and treatment system. Ann. UMCS, Sect. E, 55(2): 9-21.

Zhang J., Weaver S.E., Hamill A.S. 2000. Risks and reliability of using herbicides at below-labeled rates. Weed Technol. 14: 106-115.

\section{Różnorodność biologiczna chwastów w lanie pszenżyta ozimego (Triticum rimpaui Wittn.) w zależności od zróżnicowanych dawek herbicydów oraz nawożenia dolistnego}

\section{Streszczenie}

Doświadczenie polowe przeprowadzono w latach 2006-2008 na glebie bielicowej niecałkowitej. Badano wpływ zróżnicowanych dawek herbicydów Mustang 306 SE i Attribut 70 WG oraz nawozów dolistnych Insol 3 i FoliCare 18:18:18 na bioróżnorodność chwastów w łanie pszenżyta ozimego 'Todan'. Florę segetalną oceniano 6 tygodni po zastosowaniu herbicydów oraz przed zbiorem pszenżyta. Herbicydy stosowano łącznie $w$ pełnych zalecanych dawkach, zredukowanych do $75 \%$ oraz w dawkach zmniejszonych o połowę. Opryskiwanie nawozami dolistnymi wykonano dwukrotnie w okresie wegetacji. Obiekt kontrolny stanowiły poletka, na których nie stosowano zarówno herbicydów, jak i nawozów dolistnych.

W łanie pszenżyta ozimego dominowały Matricaria maritima i Viola arvensis z klasy dwuliściennych, z jednoliściennych zaś Apera spica-venti. Skuteczność chwastobójcza obniżonych dawek herbicydów była słabsza niż pełnych zalecanych dawek odpowiednio od 6 do $9 \%$ w pierwszym terminie oceny zachwaszczenia i od 4 do $8 \% \mathrm{w}$ drugim. Jednocześnie powietrznie sucha masa chwastów na obiektach herbicydowych nie różniła się istotnie. Wskazuje to na możliwość obniżenia dawek herbicydów w łanie pszenżyta ozimego bez ryzyka zwiększenia poziomu zachwaszczenia. 